\title{
Wielkie Księstwo Litewskie a Moskwa. Okres Smuty
}

Henryk Wisner 


\section{Henryk Wisner}

\section{Wielkie Księstwo Litewskie a Moskwa. Okres Smuty}

1

Ylut wymaga komentarza. Od roku 1569 , kiedy zostala zawarta unia nazwana lubelska, Wiclkic Księstwo Litewskic i Korona Polska miały wspólnego wladcę, którego następców powinny razem wybierać, i jeden sejm. Prawa i obowiązki panującego wynikaty z prawa zwyczajowego (niepisanego) oraz pisanego: z przywilejów, z uchwalonych w roku 1573 przez sejm elekcyjny Artykutón hem)'kon'skich i Pacta con'enta, konstytucji i zatwierdzonego w roku 1588 przez Zygmunta Wazę Statumu liteuskiego. Wszystko to, bezpoślednio i pośrednio, okrcślalo takze kompetencje sejmu.

Odrębne, koronne albo litewskie, pozostawaly terytoria, urzędy, skarb, wojsko. Nie powiodlo się zapowiedziane w konstytucji sejmu 1569 roku ujednolicenie systemu prawnego Rzeczypospolitej. Każde z jej paristw mogło, choć w ograniczonym stopniu, prowadzić politykę zagraniczną. Akt unii zezwalal inn na wysyłanie poselstw, z tym że jeżeli w ważnych sprawach, należało to czynić "za wiadomością i radą wspólną”. To ostatnie miało zapcwnić jedność działania, ale i zapobiec sytuacji, w której król, wspóldzialając tylko z jednym państwem Rzeczypospolitej, przesądzał postawę drıgiego. Kwestią odrębuą jest, że zapis byl ułomny, gdyź nie określał, co należalo do spraw ważnych, oraz kto i w jaki sposób miałby decydować o wystaniu poselstwa. W Artykutad henrykourskid wprawdzie zapisano, że postowie mają być wysylani za wiedzą i zgodą senatu przez króla; ponadto, że obic instytucje, król i senat, nie mogą decydować w sprawach zastrzezonych dla sejmu, czyli, między innymi, wypowiadania wojny i zawierania pokoju. W wypadku poselstw jednak najwyraźniej chodziło o te reprezentujące króla i oba państwa Rzeczypospolitej. W dodatku sejm, jeśli i miewal jakąś bezpośrednią kontrolę, to sporadycznie. Dla stosunku szlachty do decyzji królewskich ważna zaś byla nie litera prawa, lecz stopień ich zgodności z interesem Rzeczypospolitej, czy tylko whasnego państwa, Litwy bądź Korony, tak jak go pojmowala. Świadectwem tego możc być milczenie sejnuı w roku 1609 w sprawie przygotowań Zygmunta III do uderzenia na Moskwę oraz 
gwaltowne przeciwstawienie się w 1646 planowi Wladyslawa Wazy wojny z Turcja. Jednocześnic, w czasie wojny szwedzkiej 1625-1629, dochodziło do zawierania rozejmów, które ograniczały się do terytorium jednego państwa. Glośnym echem odbil się w Koronie zawarty przez Wielkic Księstwo 19 stycznia 1627 (Baldemmojza). Wówczas Zygmunt III zarzucił Litwinom nieposłuszeństwo (bo złamali jego powtarzane zakazy), magnaci i szlachta koronna naruszenie unii (gdyż decyzję o zawieszenniu działań podjęli przybyli na sejmik wileński senatorowie). Ani król, ani szlachta koromma, nie oglosili przecież ukladu za nieważny. Innymi słowy, nie zakwestionowali prawa Litwinów do jego zawarcia. Korona zawarła odrębne układy ze Szwedami w latach 1627 i 1628 , z tym że miała aprobatę królewską.

Zawarcie rozejnu $w$ dobie regnum przez jedno z państw Rzeczypospolitej bylo możliwe w sytuacji, gdy prowadziło walkę na odrębnym terytorium; w wypadku wspomnianej wojny szwedzkiej - kicdy oddzialy Wiclkicgo Ksiçstwa walczyły w Inflantach i na pograniczu litewskim, koronne w Prusach i Wiclkopolsce. Natomiast w dobie interregnum Litwa, budząc sprzeciw Korony lub nie, zwracała się do paístw postronnych, tak jak w czasie pierwszych bezkrólewi, kiedy podejmowała rozmowy z carem w sprawic jego (lıb carewicza) wyboru na tron polski. Wlatach 1632 i 1648 zaś wysłala posłańców do Moskwy i szwedzkiego namiestnika Inflant z wezwaniem do przestrzegania rozejmów.

Rekapitulując, Wielkie Księstwo Litewskie, jako państwo, miewało pewną swobodę działań przysługujących suwerennemu paístwu. Nie miało jej w okresie smuty, gdyż jeden był teren, na którym walczyły wojska obu państw Rzeczypospolitej, a przede wszystkim, ponieważ okresowo w obozie przebywal król. Tym samym, można mówić tylko o ówczesnym stosunku społeczeństwa, nie: państwa, litewskiego do Moskwy i tylko pośrednim, poprzez wyrażanie opinii przez senatorów i szlachtę, oddziaływaniu na decyzje króla.

Od schyłku wieku XVI po drugie dziesięciolecie XVII stosunek szlachty Wielkiego Księstwa do Moskwy, a dokładnie. do stosunków z nią, zmienial się dwukrotnie. Pierwszy okres trwal do początków panowania Wasyla Szujskiego (1606-1610). Stosunek do Moskwy kształtowany był najpierw przez paniçć porażek doznawanych od schylku XV wicku. Poczucie niemożności przeciwstawicnia siç sąsiadowi wlasnymi silanı umocniły decyzje Zygmumta Augusta, które poprzedzily, czy nawet wymusiły zawarcie unii lubelskiej. Mowa o przylączenia niemal trzeciej części terytorium Wielkicgo Księstwa, Wołynia, Kijowszczyzny i Podlasia, do Korony. Nie wydaje siç, aby nastroje uległy zasadniczej zmianie po unii, a nawet po zwycięstwic polączonych sil polsko-litewskich, które ukoronowal rozejm w Jamie ZapoIskim (1582), skoro cienicm na nim legła świadoność trudów kampanii, ogromu strat, przede wszystkim nicmożności zdobycia P'skowa. W rezultacie, zwycięstwo traktowano jak epizod. Dodać trzcba, żc jeszcze ponad ćwierć wicku później l’iotr lalczowski, autor wydanej w Wilnie $W_{j}$ pran'y Króla Jegonnosici, uwazat za potrzebne thumaczyć, że ponowne pokonanie Moskwy jest możliwe, iz „król Stefan pokazał to, że ten diabeł nic byl tak straszny, jako go malowano”. 
Tymczasem Wielkie Księstwo chcialo zapewnić sobie bezpieczeństwo w drodze pokoju, nie wojny. Wyrazem tego byly próby podejmowane w czasic bezkrólewi porozumienia siç z najpierw z Iwanem Groźnym, później Fiodorem, w sprawic ich wyboru na tron polski, czyli unii personalnej i popieranie kandydatur na polu elekcyjnym. Marginesowo moźna wspomnieć, ze w roku 1587, gdy wśród zebranych na elekcji możnych i szlachty koronnej doszlo do rozłamu, kiedy jedni wybrali królem szwedzkiego następcę tronu Zygmunta Wazç (19 sierpnia), drudzy arcyksiçcia Maksymiliana Habsburga (22 sierpnia), Litwini zaproponowali, aby unieważnić decyzje, dołączyć cara Fiodora do królewicza i arcyksięcia i wylonić władce poprzez losowanie: „Posłowic od l'anow Rad Litewskich [... podali [.. | medimm, aby ci trzej, Szwed, Moskwicin i Rakuszanin, przez los obierani byli"'. W wypadku projcktów zawarcia unii rzeczowej sprawa jest o tyle trudna, że nie został zidentyfikowany autor bądź autorzy. Można tylko przypuszczać, że co najmmicj zmali je wojewoda wileniski Krzysztof Radziwilt „Piorun”, kanclerz koronny Jan Zamoyski i Lew Sapieha. Nie wiadomo, czy postawa Litwinów zaważyla na decyzji Zygmumta III przedstawienia propozycji Moskwie. W kazdym razie, pierwszą zawieźli poslowie w roku 1590) (podkanclerzy litewski Gabriel Wojna, pisarz wielki litewski Maciej Wojna, wojewoda podlaski Stanisław Radzimiński), druga w 1600) (Lew Sapielıa, pisarz wiclki litcwski Eliasz Pielgrzymowski, kasztelan warszawski Stanislaw Warszycki). Wobu wypadkach dane postom instrukcje zalecały doprowadzanie do zblizcnia panistw i spoleczeństw. Pierwsza proponowała, między innymi, swobodne przesiedlania się ludności². Druga mówiła o przyszłym, co nie znaczy: rówıoprawıym, zjednoczeniu państw pod bertem wspólnego władcy ${ }^{3}$. Następcą (jodunowów bylby władca Rzeczypospolitej, a jeśli umarthy pierwszy, wyboru następcy dokonalby naród szlachecki i tylko postowic moskicwscy. Co więcej. wybierać mieli spośród królewiczów, a dopiero gdyby ich nie było, oddać koronę carowi. Ponadto przewidywano odrębność urzẹdów i terytoriów, jak równicż, już z chwilą zawarcia ukladu, swobodę przemicszczania siç lıdności oraz wspóldziałanie w polityce zagranicznej i obronnej.

Bez wątpienia, akceptacja propozycji przez stronç moskiewską niałaby nieprzecenione znaczenie dla układu sit w Europic, dla sytuacji miçdzynarodowej i wewnçtrzncj obu państw, w tym, dla ich ustroju. I) la Rzeczypospolitej oznaczalaby przekształcenie jej w dziedziczne królestwo najpierw Wazów, później whadców Moskwy. Propozyça została jednak przez stronę moskiewską odrzucona. Postowie nie zdolali zawrzé nawet pokoju, a jedynie przedlużyli

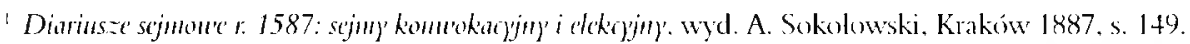

${ }^{2}$ M. Szczerbatow Istorija rossijskaja, t. 6.cz. 2, Picticrsburg, 1790), s. 227-237: B. Floria, Russkijo-polskijo otmosz'-



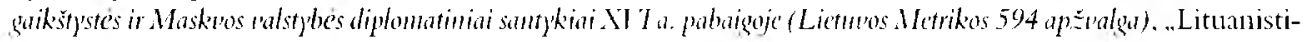
ca”, Vilnius. 20(1)2, ur 3, s. 3-32 Nakczy jedynic zastrzec. że autor omawia stosunki z państwem moskicwskim nic Wickkiego Księstwa Litcwskicgo. lecz Rzeczypospolitcj.

'Biblioteka Polskicj Akademii Umicjętności i Polskiej Akadenii Nauk w Krakowic (dalcj: BPAU-PAN Kr). rps 1(150), s. 1-44. Diaruusz poselstwa Lwa Sapichy do cara Borysa Godunowa, 5 X-9 XIl 1600); K. Tyszkowski,

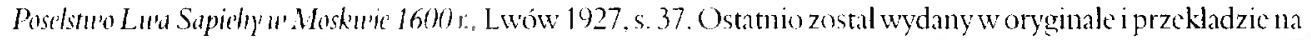

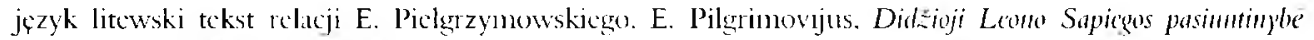
i. Mosk'n, parenge I. Kiaupicue. Vilnius 20012.
} 
rozejm o dwadzieścia lat, do roku 1622. Car zatwierdzil go w Moskwic 11 marca 1601 roku, król uczynit to w Wilnie 17 stycznia 1602 roku$^{+}$. Marginesowo można zauważyć, że zastrzegl przy tym, że układ nie obowiązuje go jako władcy Szwecji, wówczas zdetronizowanego, ale walczącego o odzyskanie tronu.

Zbrojny konflikt takze Rzeczypospolitej ze Szwecją wybucht w roku 1600 i wbrew nadziejom na latwe zwycięstwo stawał się coraz większym ciężarem, zwłaszcza dla Litwy. Działania prowadzono wprawdzie poza jej granicami, bo w Inflantach, ale nie zmieniało to konieczności oplacania wojska, a przede wszystkim znacznego zmniejszenia bezpieczeństwa wewnętrznego w wyniku przemarszu czy pobytu w Wielkim Księstwic niekarnych chorągwi. W rezultacie, wiadomość, która grozila co najmniej zaostrzeniem stosunków z Moskwą, wywołala niepokój. Mowa o liście Zygmunta III z lutego 1604 roku, w którym pisal, ze w Rzeczypospolitej przcbywa czlowiek podający się za Dymitra, syna Iwana Groźnego, i pytał senatorów, co należy w tej sytuacji zrobic ${ }^{5}$. W odpowiedzi starosta żmudzki Jan Karol Chodkiewicz przestrzegł przed decyzjami, które spowodıja, że Moskwa uzna rozejm za zerwany:

Idzie o przymjerze, które wzruszone, nigdy pociesznego efektı nie odniosło".

Wojewoda wileński Mikolaj Krzysztof Radziwiłl Sierotka pisal do kuzyna, podczaszego litewskiego Janusza Radziwilla, że przede wszystkim należy kończyć wojnę ze Szwecją:

Odprawić by pierwej Intlanty, dopiero o Moskwie pomyślcé ${ }^{7}$.

Podczaszy, komentując przygotowania podjęte przez wojewodę sandomierskiego Jerzego Mniszcha do zbrojnego poparcia Dymitra w jego walce o tronu Moskwy, wyraził opinię, ze jeśli oddziały przekrocza granicę, będzie to mialo fatalıe następstwa:

Rzeczy takie [...] nie mogą być zadną miara.jeno, ze złym, a bodaj i nie ze zgubą Ojczyzny".

Ostrzej pisal Lew Sapieha, bo stwierdzal, ze nawet sukces Dymitra będzie mial szkodliwe następstwa:

Lubo mu się poszczęści, albo nie, jednako źle Ojczyźnie i nam uczynị.

\footnotetext{
+ Tekst ukladu: Sbonik impicratorkego russkego istoricaekogo obsaczestura, t. 137. Moskwa 1912, s. 58-73: Archiwum Glówne Akt Dawnych w Warszawić. Archiwum Radziwillowskic (dalcj: AR), dz. I, nr 903: Rozejm cara Borysa Iwanowicza z krókem Zygmuntem III. 160) ; Nacionalnaja Biblioticka Rossii. Pietiersburg. Otdict Rukopisicj. Polskijo awtografy iz sobranija P. P. Duborowskogo (dalcj: Awt.) 152, k. 66-71. O przynicrzu z Moskwą, 5-20 I 1602 Wilno.

5 Ostatnio: A. Andrusicwicz. Dzicje widlkicj smmt), Katowice 1909. W pracy znajduje siç obszcrna bibliografia.

- BPAU_PAN Kr. rps 931, k. 44. Jan Karol Cloodkicwicz do Zygmunta III, 19 III 1604 Ryga.

${ }^{7}$ Ardin'mu Domm Radziurithow, uyd. A. Sokolowski. Kraków 1885, s. 51 : Mikolaj Krzysztof Radziwill Sitrotka do Janusza Radziwilla, 7 III 1604 Nieśwież.

${ }^{*}$ AR, dz. IV. nr 172: Janusz Radziwill do Mikolaja Krzysztofa Radziwilla Sicrotki, 14 IX 16014 Stara Wies.

"AR. dz. V. nr 1.385.5: Lew Sapicha do Mikolaja Krzysztofa Radziwilla, 10 XI 160)+ Ikaźn.
} 
Kwestią odrębna jest, czy Janusz Radziwill i Lew Sapichia uważali za Ojczyznę Wielkie Księstwo, czy już całą Rzeczpospolitą. W czasie sejun 1605 roku popieraniu Dymitra sprzeciwili się: biskup wileński Abraham Wojna i marszalck wielki litewski Krzysztof Dorohostajski. Ten ostatni przypomnial, ze król nic może naruszyć rozejmu, gdyż zaprzysiagł go nie tylko we whasnym imieniu, ale i calego narodu:

Przysiągleś Wasza Królewska Mość na pokój z osoby swej, przysiągleś za nas sènatory, przysiągteś i za stan rycerski...".

Zreszta, jak większość Litwinów wzywal do zatroszczenie się o lntlanty, gdzie wojsko, nic otrzymując zoldu, nie chcialo walczyć.

O stanowisku ogólu szlachty pelniejszej wiedzy dostarczylyby instrukcje na sejm (20 stycznia - 3 marca 1605). Ze znanej w kilku odpisach instrukcji sejmiku słonimskiego wynika, że godzono się na omawianic problemu, jaki stworzyła obecność Dymitra, ale nie na naruszenic rozejunu: „Ostrzegając... przysięgi Króla Jegonności i pokoju Rzeczypospolitej”" Można się domniemywać, ze podobny był ton i innych instrukcji.

Jesienią 1604 roku Dymitr, któremu Zygmunt III jednak udzielił, choć nieoficjahnie, poparcia, wkroczyl w granice Moskwy. Po pierwszych sukcesach ponióst klęskę pod Dobryniczami (31 stycznia 1605), co wzmoglo w Litwic obawy przed odwetem. W rezultacie, obradująca w początkach maja 1605 roku konwokacja wileńska podjęła z powodu „niebezpieczeństwa z granic moskiewskich" uchwalę o przeprowadzeniu jesienią, 8 września, okazowania, czyli sprawdzenia gotowości bojowej szlachty, które moglo przybrać formę pospolitego ruszenia ${ }^{12}$. Sytuacja w Moskwie ulegla jednak niespodziewanej zmianic. Zmarł Borys Godunow, jego syn i następa Fiodor zostal zabity, i na tron powolano Dymitra (triumfalny wjazd do Moskwy 30 czerwca, koronacja 31 lipca 1605). W rezultacic Lew Sapieha, zapominając o swych prognozach, stal się rzecznikiem umacniania z carem najlepszych stosunków. Wiosną 1606 roku wspominal, że właśnie na jego usilne nalegania król wysłal do Moskwy swego komornika Krasowskiego z podarunkanni z okazji ślubu Dynitra i Maryny Mniszchówny ${ }^{13}$. Dodać można, że przekazą je wielcy posłowie króla, Korony i Wielkiego Księstwa, kasztelan małogoski Mikolaj Oleśnicki i starosta wielishi Aleksander Gosiewskit.

Gównyn zadaniem postów bylı podjęcie po raz kolejny rozmów w sprawie zawarcia przez Rzeczpospolitą i Moskwę czegoś w rodzaju federacji czy choćby sojuszu. Juz nie wspominano, jak w roku 1 ou(), o zespoleniu pod berlem jednego whadey, a tylko, miçdzy innymi, o jedności polityki zagraniczncj i swobodzie przemieszczania się ludności. Zbiegienn jednak

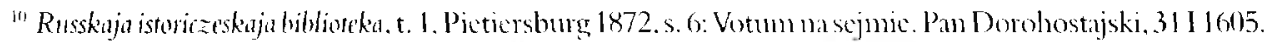

"BPAU-PAN Kr. rps 365. k. 1 H: Instrukcja stonimska dana postom na scjm: Janowi Micleszce i Mikolajowi Tryźnic, 9 XII Dzicwitteowice.

1: Bibliotcka Zakladu Narodowego im. Ossolińskich we Wroctawiu, rps 2284, k. 137.

${ }^{17}$ Teki Naruszewicza (dalcj: TN), t. 101. nr 22: Lew Sapicha do Mikolaja Oléśnickicgo, 6 IV 1606.

${ }^{14}$ Bibliotcka Czartoryskich w Krakowic (dalcj: ( zart.). rps 3+2. ur +3: 1) iaritusz dzicjów moskicwskich i lcgacji... Mikolaja Oleśnickicgo... Alcksandra Korwina (rosicwskicgro... spisany w roku 16066 w Mushwic.
} 
okoliczności, gdy przystapiono do rozmów (25 maja 1606), w Moskwie wybuchlo powstanie, Dymitr zginąl (26/27 maja 1606). Na tron wstąpił wrogi Rzeczypospolitej Wasyl Szujski (1606-1610), który uwięził Marynę, posłów, przebywających w stolicy Polaków (część jednak wcześniej zginęła). W Rzeczypospolitej. gdzie właśnie nasilał się ruch, który przybierze formę rokoszu Zebrzydowskiego, wywolalo to dośc różne echa. W obozie rokoszowym uznano, że jest to kara Boża za pychę, którą Dymitr okazał posłom królewskim, a zatem samemu królowi i calemu narodowi szlacheckicmu ${ }^{15}$. W Litwic i na moskiewskim pograniczu Korony odrodzila się obawa przed odwetem. W rezultacie. z pewnościa szlach ta mińska, witebska, a pewnie i inna, uznala wyjazd na zjazd rokoszowy za niemożliwy. Wysłanym postom sejnik witebski nakazal prosić o obnyślenie obrony granicy ${ }^{10}$. Posłom wysłanym zaś na sejm (7 marca-18 kwietnia 1606) zleci prosić króla, żeby staral się o uwolnienie Polaków, których nadal więziono w Moskwie, ale środkani dyplomatycznymi, .przez posty"17.

Początek okresu drugiego przypada na pierwsze miesiące panowania Wasyla Szujskiego. Proces zmiany postawy rozpocząl się w Litwie chyba już późna jesienią 1606 roku, w środowisku drobnej szlachty, dla której dostrzeżona slabość państwa moskiewskiego stała się impulsem do grabieżczych wypraw. Jak można przypuszczać, licznych, bo wywołały interwencję króla, który w marcu 1607 roku wydał adresowany do wojewodów, starostów i szlachty powiatów pogranicznych uniwersal, w którym nakazywal przeciwdziałanje ${ }^{15}$. Wydaje się wątpliwe, aby podjęto próby wykonania polecenia króla. W kazdym razie, wyprawy w gląb Moskwy nasiliły się, zwłaszcza gdy latem 1607 roku pojawil się, potęgując chaos, kolejuy jak głoszono: raz jeszcze cudownie uratowany — Dymitr, a w rzeczywistości polska kreatura.

Zapewne ten sam czynnik, czyli słabość państwa moskiewskicgo, oddzialał na postawę magnatów litewskich. Żaden wprawdzie samowolnie nie ruszyl do Moskwy. Częściowym wyjątkiem jest starosta uświacki Jan Piotr Sapieha, który wprawdzie magnatem nie byl, ale należał do rodı magnackiego. Nie wiadomo zresztą o tym, aby Lew Sapicha potępil kuzyna. Z jego listu datowanego 11 sierpnia 1608 roku przebija jedynie obawa przed konsekwencjami ewentualnej porazki:

Jcśliby się tam naszym noga powinę̧ła [...] obawiać się potrzeba, by ten nieprzyjaciel rozdrazniony nie chciał na nas ubezpieczonych mścić się krzywdy swej".

\footnotetext{
is AR. dz. V. nr 15367: Jan Sulkowicz do Mikolaja Krzysztofa Radziwiłla Sicrotki. 31 VIII 16066 z Lenarcic pod Sandomicrzem.

${ }^{16}$ AR, dz. Il. nr jo): Instrukcja mińska dana dziewięciu posłom na zjazd rokoszowy. 17 VII 16016 Mińsk: Czart. rps 224t. nr 26: Informacja pustom: Ostaficjowi Kurczowi i Adanowi Kosowi wystanym na zjazd glówny rokoszowy pod Sandomicrzem. 21 VII 16060 Witebsk.

${ }^{17}$ TN. t. 103, ur 27: Instrukcja witcbska dana postom na scjun: Mikotajowi Hlchowiczowi i Alcksandrowi Sapiesze. 26 III 1607 Wirebsk.

1* BPAU-PAN Kr. rps 34t. s. 97. Zygmumt III do Lwa Sapichy: 14 11 II 1607 Kraków.

"AR. dz. V, nr 13855: Lew Sapicia do Janusza Raciziwilla, 6 VIIl 1608 Kraków:
} 
Wspomniane ubezpieczenie to zawarty z Wasylem Szujskin rozejm, który miał obowiązywać od 20 lipca 1608 roku przez 3 lata i 11 miesięcy.

Brakuje informacji, żeby w roku 1608 przygotowania Zygmunta III do wojny budziły w Litwie powszechmiejszy sprzeciw. Znamienny w tym względzie moze być list Krzysztofa Radziwiłła do przyrodniego brata, Janusza, a sciślcj, utrzymana w spokojnym tonie informacja, że Zygnumut III nakazał zaciagać wojsko, by po zawarciu przymierza z władcą Szwecji Karolem IX uderzyć na Moskwę i silą prowadzić na tron królewicza Władysława 21". Nie wiado1mo, zeby w 1609 rokı, w czasie narady senatu, który, choć niejednoglośnie, upoważnil króla do rozpoczęcia dzialań, lub po nicj senatorzy Wielkiego Księstwa przeciw temu zaprotestowali. Owszem, gdy król ruszył pod Smolerísk, towarzyszyli mu miçdzy innymi Krzysztof Dorohostajski, Lew Sapieha, powoli awansujący w hierarchii społecznej Aleksander Gosiewski i pisarz litewski Janusz Skınin Tyszkiewicz, a z czasem dołączy hetman wielki litewski Jan Karol Chodkiewicz. To ostatnic wywolato jednak nieprzychylne komentarze. Jak pisal do niego Hieronim Chodkiewicz,

mów uszczypliwych i animuszów tak nammożyło od Waszmości [...] odwróconych, ze tego pelna Litwa i Polska ${ }^{21}$.

Krytykę wywolala jednak nie tyle sama decyzja, ile jej sprzeczność z nièukrywanymn weześnicj negatywnym stosunkiem hetmana do mieszania się w sprawy Moskwy. Nieugiętym przeciwnikiem wojny pozostal Janusz Radziwill, który jeszcze w roku 1611 przyznawal rację tym wszystkim, którzy się ,ani rada, ani groszen do tej moskiewskicj wojny nie przyktadali”ㄹ.2.

Niewątpliwy sukces króla, jakim było zdobycie Smoleńska (13 czerwca 1611), okazal, ze - zdaniem Litwinow - celem wojny było odzyskanie terenów utraconych w poprzednim stuleciu, a zajęcie twierdzy jego osiagnięciem. Odtąd bowiem, najpierw w korespondencji, potem w instrukcji sejników, pojawia się problem ich przyszlej przynależności. Wspominany Janusz Radziwill, dzjękując Bogu za odıiesiony sukces, zastanawial się, czy król przyłączy twierdzę, i w ogóle księstwo smoleńskie, do Korony czy do Litwy:

Obaczymy, czy bardzicjw Panu przemaga afékt ku Koronic, czy krew jagiellońska ${ }^{23}$.

Opinia księcia zasługuje zresztą na uwagę także z innego powodu, mianowicie, iż za upoważnionego do zmiany terytorium kazdego z państw Rzeczypospolitej uznawal króla, a nie sejm. Cowięcej, tak samo uważaly sejmiki, w których uchwalach problem wcielenia opanowanych terenów do Wielkiego Księstwa występować będzie z narastającą siłą:

"AR. dz. IV, 11 298: Krzysztof Radziwill do Janusza Radziwilla. 19 XI I608 Wiz.111y.

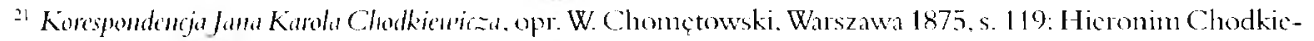
wicz do Jana Karola Chodkicwicza, $27 \mathrm{~V}$ loll Wilno.

2 TN. t. 106, ne 15: Janusz Radziwill do Lwa Sapichy. 3 V 1611 Kojdanów.

21 AR, dz. IV, n1 172: Jamusz Radziwill do Mikolaja Krzysztofa Radziwilla Sicrotki. 22 VI 1611 Dolatycze. 
Smoleńsk i wszystka Ziemia Siewierska, jako przedtemn do Wielkiego Księstwa Litewskiego należała, tak, aby teraz $[\ldots]$ inkorporowana $[\ldots]$ była -

zastrzegal juz w sierpniu 1611 roku sejmik wileríski, i podobnie wszystkie inne, których instrukcje są znane ${ }^{2+}$. Jednocześnie sejmiki: miński i oszmiański domagały się zakoníczenia wojny droga rokowań, a dopiero gdyby nic przyniosły skutku, wymuszenia go siłą ${ }^{25}$. Sejmik polocki i żmudzki mówily o obronie granic ${ }^{26}$. Sejmik wileński poprzestal na zgodzie na uchwalenie przez sejm podatków przeznaczonych na wojnę. W sumie, przynajmniej część sejmików, z pewnością polocki i żmudzki, nie traktowały ogromu odniesionego sukcesu militarnego za trwałą wykladnię stosunku sił między Rzecząpospolita a Moskwą. Ba, połocki nawet zażądał ujawnicnia i ukarania ludzi, którzy mieli namówić króla do rozpoczęcia wojny ${ }^{27}$.

Nie wiadomo, co było powodem, że mimo silnych wcześniej nastrojów unijnych, milczano o elekcji królewicza Whadyslawa na tron carski (1610), a z czasem - o prawach do niego. Bazując na obecnym stanie badań, można jedynie domniemywać, że przede wszystkim uważano zyskanic przez nicgo korony za niereahne, a nawet - choć bylo to oczywiście sprzeczne z projektem unii, jaki w roku 16001 przedstawil w Moskwie Lew Sapieha - za niekorzystne dla Rzeczypospolitej. Spodziewana clekcja Władysława i na tron polski musiałaby bowiem doprowadzić do niezmiernego wzrostu wladzy monarszej, a zatem uszczuplenia praw szlachty.

Przynajmniej część statystów litewskich opowiadających się za szybkim kończeniem wojny zwracała uwagę, ze współdziałanie Moskwy i Szwecji zaowocuje klçską Litwy i całej Rzeczypospolitej. Jak mówił - co prawda kilka lat później, bo w czasie sejunu 1618 roku — podkanclerzy litewski Eustachy Wollowicz:

gdzieby stantąd [z Inflant] i z Moskwy oraz na nas nastąpiono, pewnie by już nie o Wilno, ale o Wisłę [...] opieral się nieprzyjaciele ${ }^{2+}$.

W okresie trzecim, nastroje ksztaltowała świadomość odradzania sį̨ potęgi Moskwy, co okazala kapitulacja stacjonujących w stolicy polskich choragwi (1612), nicpowodzenie kolejnej wyprawy Zygmunta III, czy próba siçgniçcia po utracone tereny, w tym blokada Smoleńska, przez pulki nowego cara Michała Romanowa. Jednocześnie grabieże, gwalty, zabójstwa dokonywane przez zbrojne gromady skupiające ludzi różnego stanu i narodowości, ale zawsze niepomnych na prawo Boskie $i$ ludzkie, stały się plagą odczuwaną w całym Wielkin

\footnotetext{
${ }^{2+}$ BPAU-PAN Kr. rps 365, k. H: Instrukcja wilcriska dana poslon na sejn, lanowi Sapiesze I lanowi Czyzowi, 17 VIII 1611 Wilno.

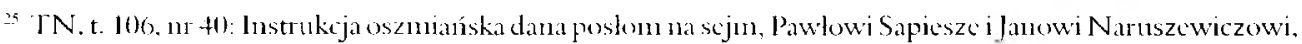
15 VIII 1611 Oszminam.

${ }^{2 n}$ BPAU-PAN Kr: rps.360. k. 218: Instrukcja żmudzka dana poshom na scjm: Malcherowi Szemc towi i janowi Thlatowi. 15 VIII 1611.

${ }^{27}$ BPAU-1PAN Kr. rps 36,5. k. 49: Instrukcja polocka dana postom na scjun. Piotrowi Stabrowskicmu i Alcksandrowi Tyszkicwiczowi, 15 VIII 1611 Potock.

2s Biblioteka PAN w Kómiku. rps 326. k. 301: Votum ks. Eustachego Wollowicza biskupa wileńskicgo, podkanclerzego Wiclkiego Ksiçstwa Litewskicgo. 21 II 1618.
} 
Księstwie. Wszystko spowodowało nasilenie się krytyki podjęcia wojny. W roku 1613 przedsejmowe sejmiki litewskie: oszmiański, wileński i wilkonierski, a pewnie i innc, których instrukcje nie są znane, zażądały ujawnienia doradoów królewskich, którzy rádzili zerwanie rozejinu:

Radzibyśsny [...] wicdzieli [...] kto wżdy był tak wielkiej Rzeczypospolitej szkody przyczyną i radą.

W. 1615 żądal tego sejmik nowogrodzki, przy czym w jego wypadku zwraca uwage uzasadnienie, ze wojna nie tylko

mało nie ostatnią zģubę Ojczyźnie naszej przyniosla, z dostatków zlupila, niezliczonej kupy ludzi rycerskich pozbawila.

alc takze, iż okryla Rzeczpospolitą nieslawą: „Do postronnych krajów w olyydę i hańbę wprawila"'" . To samo, tyle że z pominięciem aspektu międzynarodowego wojny, wpisala w instrukcję poselską szlachta niniska: aby

autores wojny tej moskiewskicj, która nam i Ojczyźnic naszej wszystko zlo przyniosla $[\ldots]$ karanie odnieśliin

Na opracowanie czeka problem wiedzy, jaką w toku wojny zyskano w Litwie o państwie i spoleczeństwie moskiewskim. Pewne, ze było parę dróg poznania: udział w wojnie, relacje uczestników, utwory literackie, wreszcie kontakt z jeńcami, ludźni uprowadzonymi i tymi, którzy przybyli dobrowolnie. Należy jednak dodać, że ich liczba nie jest znana nawet szacınkowo. Być może, że o dość szerokim zasięgu zjawiska świadczy fakt, iż Moskwicini przebywali nawet na dworze Krzysztofa Radziwilla, który w dzialaniach na terenie panstwa moskiewskiego nie uczestniczyl. Jak wynika z listu Lwa Sapiehy pisanego po zawarciu rozejmu dywilińskiego, kanclerz przyslał księciu „dla roboty haftarskiej dwie Moskiewkj”. Teraz, wyrażając nadzicję, żo wyuczyly następczynie, prosil o odeslanie ich, aby zgodnic z postanowieniami rozejmu mogly wrócić do domów ${ }^{31}$.

Rekapitulując: w postawie Wielkiego Księstwa Litewskiego wobec Moskwy wyróżnić można trzy glówne okresy. Pierwszy, który trwal do początków panowania Wasyla Szujjskiego (1606-1610), cechuje dązenie do trwalego zakoniczenia konfliktu poprzez zawarcie unii personalnej lub rzeczowej, pokoju, a choćby długotrwatego rozejmu. Drugi obejmuje lata od wstąpienia na tron Wasyla Szujskiego, a ściślcj, od uwidocznienia się niemożności zapanowania nad krajem. W tym czasic doclıodzi najpierw do samowolnycl wypraw podejmowanych

\footnotetext{
" BPAU-PAN Kr. rps 365. k. 70. Urazy w swobodach i wolnosciach. i prawach naszych podanc... postom na scjm... l615̄ zs smiku nowogrodzkiego, Albryclenwi Wladyslawowi Radziwillowiilanowi Protasowiczowi.

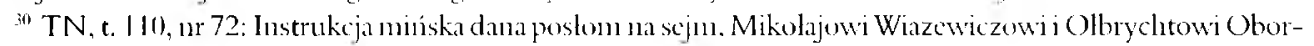
skicmu1, 2 I 1618 Minsk. Data roczma blędna. powimno byc: 1615.

${ }^{3}$ Licturos Mokslu Akadenijos Biblioteka. Vilnius. Rkps F 9-432. [) wa listy Lwa Sapichy do Krzysztofa Radziwilla: s. 12. List bez daty alc po zawarciu rozejum dywilinskicgo: s. 14 . List ponaglajacy $9 \mathrm{~V} 1619$.
} 
przcz ludzi, którzy nic znajdowali dla siebic miejsca i chleba w Ojczyźnie, później do udzielenia biernego i czymnego poparcia przez magnaterię litewską decyzji Zygmunnta III podjęcia wojny. Za osiągnięcie jej celu najwyraźnicj uznawano zdobycie Smoleńska (1611). Okres trzeci zaczyna się z chwilą uwidocznienia się odradzania potęgi Moskwy, a jednoczcśnie spadku bezpieczeństwa wewnętrznego $w$ wyniku działan chorągwi zaciągniętyclı na wojnę oraz wszelkiego rodzaju gromad bezlitośnie grabiących wlasny kraj. W wystąpieniach wiązących się z wojną dominuje krytyka jej podjęcia i żądanie zakończenia, ale z zachowaniem zajętych ziem. 